\title{
Comprehensive analysis and study of the machinability of a high strength aluminum alloy (EN AW-AIZn5.5MgCu) in the high-feed milling
}

\author{
Duplák, J. ${ }^{a}$, Hatala, M. ${ }^{a}$, Dupláková, D..$^{\text {a, }}$, Steranka, J. ${ }^{\text {b }}$ \\ ${ }^{a}$ Technical University of Košice, Faculty of Manufacturing Technologies with a seat in Prešov, Department of Automobile \\ and Manufacturing Technologies, Prešov, Slovakia \\ ${ }^{\mathrm{b}}$ Technical University of Košice, Faculty of Manufacturing Technologies with a seat in Prešov, Department of Computer \\ Aided Manufacturing Technologies, Prešov, Slovakia
}

\section{A B S T R A C T}

This article is focused on studying and analysing the efficiency of the machinability of a high strength aluminium alloy (EN AW-AlZn5.5MgCu) in the high feed milling. The introduction of the article provides a brief description of high feed milling technology and presents best known research regards to the subject. The research of the time efficiency and economic efficiency of high feed milling of aluminium alloys consists of realization of two groups of experiments. The first group consists of four experiments carried out by progressive technology of high feed milling, and the second group contains one experiment conducted using conventional milling technology. The assessment of efficiency consists in determining the overall time and economic efficiency and also in comparison to the machining of aluminium alloys by high feed milling technology with conventional machining technology. The best results were obtained when the machining parameters were: cutting speed of 550 $\mathrm{m} / \mathrm{min}$, travel speed of $10600 \mathrm{~mm} / \mathrm{min}$, and feed per tooth of $0.85 \mathrm{~mm}$. The material was removed in the contour roughing phase with a $42 \mathrm{~mm}$ plungecutting router. Using this cutter, it is possible to produce 19 pieces of components in a hour, which is more than half of the specified requirement. The production of components under the conditions and with this type of high feed milling cutter is more than $75 \%$ shorter than production by a conventional method.
\end{abstract}

\author{
ARTICLE INFO \\ Keywords: \\ High-feed milling; \\ High strength aluminum alloy (EN \\ AW-AlZn5.5MgCu); \\ Machinability; Efficiency; \\ Optimization \\ *Corresponding author: \\ darina.duplakova@tuke.sk \\ (Dupláková, D.) \\ Article history: \\ Received 9 July 2018 \\ Revised 24 August 2018 \\ Accepted 27 August 2018
}

\section{References}

[1] Čepová, L., Šoková, D., Malotová, Š., Gapinski, B., Čep, R. (2016). Evaluation of cutting forces and surface roughness after machining of selected materials, Manufacturing Technology, Vol. 16, No. 1, 45-48.

[2] Mital'ová, Z., Mital', D., Botko, F. (2016). Measuring of roughness and roundness parameters after turning of composite material with natural reinforcement, In: Science report: Project CIII - PL-0007: Research on modern systems for manufacture and measurement of components of machines and devices, Kielce: Wydawnictwo Politechniki Świętokrzyskiej, Poland, 49-58.

[3] Iwaszko, J., Kudla, K., Fila, K., Caban, R. (2017). Application of FSP technology in formation process of composite microstructure in AlZn5.5MgCu aluminium alloy surface layer reinforced with SiC particles, Composites Theory and Practice, Vol.17, No. 1, 51-56.

[4] Wu, H., Zhang, S. (2015). Effects of cutting conditions on the milling process of titanium alloy Ti6Al4V, The International Journal of Advanced Manufacturing Technology, Vol. 77, No. 9-12, 2235-2240, doi: 10.1007/s00170-0146645-2. 
[5] Napiorkowski, J., Mikolajczak, P., Legutko, S., Krolczyk, J. (2017). Developing of wear model of construction materials in abrasive soil pulp employing discriminant analysis, Tehnički Vjesnik - Technical Gazette, Vol. 24, Supplement 1, 15-20, doi: 10.17559/TV-20140422230704.

[6] Davim, J.P. (2011). Modern machining technology: A practical guide, Elsevier Science \& Technology, Cambridge, UK.

[7] Lei, F., Xu, Q., Zhang, G. (eds.) (2017). Machinery, materials science and engineering applications: Proceedings of the 6th international conference on machinery, materials science and engineering applications (MMSE 2016), Wuhan, China, CRC Press/Balkema.

[8] Ji, W., Liu, X., Wang, L., Sun, S. (2015). Experimental evaluation of polycrystalline diamond (PCD) tool geometries at high feed rate in milling of titanium alloy TC11, The International Journal of Advanced Manufacturing Technology, Vol. 77, No. 9-12, 1549-1555, doi: 10.1007/s00170-014-6517-9.

[9] Petru, J., Cep, R., Grepl, M., Petrkovska, L. (2011). Effect of high feed milling on the microstructure and microhardness of surface layer, Annals of DAAAM for 2011 \& Proceedings of the 22nd International DAAAM Symposium, Vol. 22, No. 1, 999-1000.

[10] Mihail, L.A. (2010). Dynamic mill's deflection for high feed machining on orthogonal directions, In: Proceedings of the 9th WSEAS international conference on Signal processing, robotics and automation, Cambridge, UK, 69-73.

[11] Mwinuka, T.E., Mgwatu, M.I. (2015). Tool selection for rough and finish CNC milling operations based on toolpath generation and machining optimisation, Advances in Production Engineering \& Management, Vol. 10, No. 1, 18-26, doi: 10.14743/apem2015.1.189.

[12] Choi, Y. (2015). Influence of feed rate on surface integrity and fatigue performance of machined surfaces, International Journal of Fatigue, Vol. 78, 46-52, doi: 10.1016/j.ijfatigue.2015.03.028.

[13] Gylienè, V., Eidukynas, V. (2016). The numerical analysis of cutting forces in high feed face milling, assuming the milling tool geometry, Procedia CIRP, Vol. 46, 436-439, doi: 10.1016/i.procir.2016.03.132.

[14] Zauskova, L., Czan, A., Sajgalik, M., Drbul, M., Rysava, Z. (2017). Triaxial measurement of residual stress after high feed milling using X-ray diffraction, Procedia Engineering, Vol. 192, 982-987, doi: 10.1016/i.proeng.2017.06.169.

[15] Childs, T., Maekawa, K., Obikawa, T., Yamane, Y. (2000). Metal machining: Theory and applications, John Wiley \& Sons, New York, USA, doi: 10.1016/C2009-0-23990-0.

[16] Valíček, J., Harničárová, M., Öchsner, A., Hutyrová, Z., Kušnerová, M., Tozan, H., Michenka, V., Šepelák, V., Mital', D., Zajac, J. (2017). Quantifying the mechanical properties of materials and the process of elastic-plastic deformation under external stress on material, Materials, Vol. 8, No. 11, 7401-7422, doi: 10.3390/ma8115385.

[17] Knežo, D., Andrejiová, M., Kimáková, Z., Radchenko, S. (2016). Determining of the optimal device lifetime using mathematical renewal models, TEM Journal, Vol. 5, No. 2, 121-125.

[18] Knapčíková, L. (2013). Examination of surface of composite materials by atomic force microscopy, Strojárstvo, Vol. 17, No. 12, 58-59.

[19] Lehocká, D., Hlavatý, I., Hloch, S. (2016). Rationalization of material flow in production of semitrailer frame for automotive industry, Tehnički Vjesnik - Technical Gazette, Vol. 23, No. 4, 1215-1220, doi: 10.17559/TV20131113 100109.

[20] Karpus', V.E., Ivanov, V.A. (2008). Universal-composite adjustable machine-tool attachments, Russian Engineering Research, Vol. 28, No. 11, 1077-1083, doi: 10.3103/S1068798X08110105.

[21] Katahira, K., Matsumoto, Y., Komotori, J., Yamazaki, K. (2017). Experimental investigation of machinability and surface quality of sapphire machined with polycrystalline diamond micro-milling tool, The International Journal of Advanced Manufacturing Technology, Vol. 93, No. 9-12, 4389-4398, doi: 10.1007/s00170-017-0881-1.

[22] Masood, I., Jahanzaib, M., Haider, A. (2016). Tool wear and cost evaluation of face milling grade 5 titanium alloy for sustainable machining, Advances in Production Engineering \& Management, Vol. 11, No. 3, 239-250, doi: 10.14743/apem2016.3.224.

[23] Neacșu, M.I., Chiriac, R.E., Chiriac, A., Pandia, O., Saracin, I. (2017). Experimental research on the influence of soaking aging type on some mechanical properties of the alloy AlZn5,7 MgCu, Metalurgija, Vol. 56, No. 1-2, 215218. 


\title{
Celovita analiza in študija obdelovalnosti aluminijeve zlitine visoke trdnosti (EN AW-AIZn5.5MgCu) pri rezkanju z visoko hitrostjo podajanja
}

\author{
Duplák, J. ${ }^{a}$, Hatala, M. ${ }^{a}$, Dupláková, D..$^{a,}{ }^{,}$, Steranka, J. ${ }^{\text {b }}$ \\ ${ }^{\text {a}}$ Technical University of Košice, Faculty of Manufacturing Technologies with a seat in Prešov, Department of Automobile and \\ Manufacturing Technologies, Prešov, Slovakia \\ ${ }^{b}$ Technical University of Košice, Faculty of Manufacturing Technologies with a seat in Prešov, Department of Computer \\ Aided Manufacturing Technologies, Prešov, Slovakia
}

\begin{abstract}
POVZETEK
Ta članek je osredotočen na proučevanje in analizo učinkovitosti obdelovalnosti aluminijeve zlitine visoke trdnosti (EN AW-AlZn5.5MgCu) pri rezkanju z visoko hitrostjo podajanja. V uvodu članka je kratek opis tehnologije rezkanja $\mathrm{z}$ visoko hitrostjo podajanja, predstavljene pa so tudi najbolj znane raziskave $\mathrm{v}$ zvezi s to tematiko. Raziskava časovne in ekonomske učinkovitosti rezkanja aluminijevih zlitin $\mathrm{z}$ visoko hitrostjo podajanja je izvedena $\mathrm{v}$ dveh skupinah poskusov. Prvo skupino sestavljajo štirje poskusi, ki so bili izvedeni s progresivno tehnologijo rezkanja z visoko hitrostjo podajanja, druga skupina pa vsebuje en poskus, ki je bil izveden z uporabo običajne tehnologije rezkanja. Ocena učinkovitosti temelji na ovrednotenju celotnega časa in ekonomske učinkovitosti ter na primerjavi obdelave aluminijevih zlitin $\mathrm{z}$ tehnologijo rezkanja $\mathrm{z}$ visoko hitrostjo podajanja s konvencionalno tehnologijo obdelave. Najboljši rezultati so bili doseženi, ko so bili obdelovalni parametri: hitrost rezanja $550 \mathrm{~m} / \mathrm{min}$, hitrost podajanja $10600 \mathrm{~mm} / \mathrm{min}$ in podajanje na zob $0,85 \mathrm{~mm}$. Material je bil $\mathrm{v}$ fazi grobe obdelave odstranjen $\mathrm{z}$ orodjem za potopno rezkanje s premerom $42 \mathrm{~mm}$. $\mathrm{Z}$ uporabo tega rezkalnega orodja je možno $\mathrm{v}$ eni uri izdelati 19 kosov komponent, kar je več kot polovica predpisane zahteve. Proizvodnja komponent pod temi pogoji in s to vrsto orodja za visoko hitrostno podajanje je več kot $75 \%$ hitrejša od proizvodnje po običajni metodi.
\end{abstract}

\section{PODATKI O ČLANKU}

Ključne besede:

Rezkanje z visoko hitrostjo poda-

janja;

Aluminijeva zlitina visoke trdnosti

(EN AW-AlZn5.5MgCu);

Učinkovitost;

Obdelovalnost;

Optimizacija

*Kontaktna oseba:

darina.duplakova@tuke.sk

(Dupláková, D.)

Zgodovina članka:

Prejet 9. julija 2018

Popravljen 24. avgusta 2018

Sprejet 27. avgusta 2018 